\title{
EFFECT OF AGROCLIMATE ON SEED AND SEEDLING TRAITS OF TREE BEAN (Parkia timoriana (DC) Merr.) IN NORTH EAST INDIA
}

\author{
Uttam Thangjam, Uttam Kumar Sahoo* and Pentile Thong \\ Department of Forestry, School of Earth Sciences \& Natural Resource Management, \\ Mizoram University, Aizawl-796004, India
}

Received: 15 August 2018, Revised: 02 February 2019, Accepted: 27 April 2019

\begin{abstract}
EFFECT OF AGROCLIMATE ON SEED AND SEEDLING TRAITS OF TREE BEAN (Parkia timoriana (DC) Merr.) IN NORTH EAST INDIA. Parkia timoriana (DC) Merr. (common name: tree bean) is a legum tree species found distributed in several South-East Asian countries including Indonesia, Japan, Malayasia, Phillippines, Thailand and Vietnam including the mid and foothills of eastern Himalayas. It was identified seed sources and grouped them into different agro climatic zones based on moisture index and precipitation. The resultant agroclimatic zones were analyzed for significant influences on quantitative traits of seeds and seedlings of P. timoriana and their contribution to germination and growth. Analysis of variance showed significant variation $(\mathrm{p}<0.05)$ in all seeds and pod traits of $P$. timoriana between agroclimatic zones. Polynomial regression showed a gradual increase in pod length, pod weight, seed weight per pod, seed number per pod and 1000 seed weight from the perhumid zone to arid zone. Zonal variations on seed germination and seedling vigour was in the order of arid $>$ humid $>$ sub-humid $>$ perhumid. It was recommended that tree breeders should choose P. timoriana from the arid zone (MI $=-20$ to -60$)$ for establishing seed orchard for optimum yield. Further, the ARCGIS interpolation tool could be used to predict better seed sources of this species in plantation programmes.
\end{abstract}

Keywords: Parkia timoriana, agroclimatic zone, moisture index, variation

PENGARUH AGROKLIMAT TERHADAP BENIH DAN SIFAT-SIFAT BIJI POHON KEDAUNG (Parkia timoriana (DC) Merr.) DI INDIA TIMUR UTARA). Parkia timoriana (DC) Merr. (nama umum: pohon kedaung) adalah spesies pohon legum yang ditemukan tersebar di beberapa negara Asia Tenggara termasuk Indonesia, Jepang, Malaysia, Filipina, Thailand dan Vietnam termasuk bagian tengah pertengahan dan kaki pegunungan Himalaya bagian timur. Tegakan kedaung di daerah tersebut diidentifikasi sebagai sumber benih dan mengelompokkannya ke dalam zona iklim agro yang berbeda berdasarkan indeks kelembapan dan curah bujan. Zona agroklimatik yang dihasilkan dianalisis untuk pengaruh signifikan pada sifat kuantitatif benih dan bibit $\underline{\mathrm{P}}$ timoriana dan kontribusinya terbadap perkecambahan dan pertumbuhan. Analisis varian menunjuk.kan variasi yang signifikan $(p<0,05)$ pada semua benih dan polong $\underline{\underline{P}}$ timoriana antara zona agroklimatik. Regresi polinomial menunjukean peningkatan bertahap dalam panjang polong, berat polong, berat biji per polong, jumlah biji per polong dan berat 1000 biji dari zona perbumid ke zona kering. Variasi zona pada perkecambahan benib dan vigor benih berada di urutan arid $>$ lembap $>$ sub-lembap> perbumid. Disarankan babwa pemulia

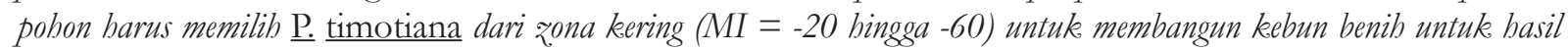
yang optimal. Selanjutnya, alat interpolasi ARCGIS dapat digunakan untuk memprediksi sumber benih yang lebih baik dari spesies ini dalam program penghijauan di areal perkebunan.

Kata kunci: Parkia timoriana, agroklimat, indeks kadar air, variasi

*Corresponding author: uksahoo_2003@rediffmail.com 


\section{INTRODUCTION}

Parkia timoriana (DC) Merr. (Family: Mimosaceae) is one of the well known multipurpose tree species of the tropics and sub tropics and has a wide distribution in South East Asian countries including Indonesia, Japan, Malaysia, Philippines, Thailand, Vietnam and Northeast India (Salam et al., 2009; 2010). This is the only species of Parkia, which is found on both sides of the Wallace's line, primarily distributed in evergreen rain forest, moist mixed deciduous and dry evergreen forests. Altitudinal variation of this species usually ranges between 0 and $600 \mathrm{~m}$, most common up to $300 \mathrm{~m}$ but rarely reaches $1300 \mathrm{~m}$ in North East India and Bangladesh, and Borneo where it grows up to the upper limit of dipterocarp forest (Hopkins, 1994).

In India the species is grown mostly in home gardens and fallow lands of shifting cultivation, and the species is in high demand for dietary supplement. The flower and fruits of this species have beneficial nutritional and medicinal properties (Rathi et al., 2012). However, the tree is vulnerable to the pest insect Cadra cautella, a moth whose larva bores into the seed to pupate, feeding on the seed interior and filling it with webbing (Thangjam, Damayanti \& Sharma, 2003).

Parkia biglobosa, another species of this genus in Africa has shown lack of regeneration and stand senescence, which might result in complete disappearance over time (Teklehaimanot, 2004; Raebild, Hansen \& Kambou, 2011). Overexploitation, insect infestation, shortening of fallow period and drier climate could cause complete disappearance of this species unless immediate measures are undertaken (Roy et al., 2016). Though anthropogenic and insect infestation poses threat to the survival of this species, climatic effects on the other hand could magnify the problem. This study evaluates the effects of source on seed, pod and seedling traits of $P$. timoriana and to examine to what extent the variability between sources reflects climatic factors.
Many studies have examined the relationship between seed source or seed zones on germination and growth both within species and between species (Xu et al., 2015; Palinikumara et al., 2015; Aigbe, Fredrick \& Omokhana, 2016; Moya et al., 2017), however, no quantitative estimates on role of species' adaptation on different climates exist for $P$. timoriana. Our analysis is designed using the climatic model of Thornthwaite (1948) and further mapping with ArcGIS (ESRI, USA) interpolation tool, which fit the provenance related climatic data of $P$. timoriana in various agroclimatic zones. Information on morphological and genetic variation of seed and pod characters are nevertheless important for afforestation and tree improvement programme (Tomar \& Rattan, 2012; Fredrick et al., 2015; Gardarin et al., 2016; Gupta et al., 2016). It was hypothesized significant variation in quantitative traits of $P$. timoriana across agro climatic zones which may help in identifying suitable seed sources for optimum resource utilization.

\section{MATERIALS AND METHOD}

\section{A. Site Selection and Zonation}

Parkia timoriana (DC) Merr. was identified using the book "Flora Neotropica" (Hopkins, 1986). The $P$. timoriana growing population in Northeast India were first extensively surveyed from market during December to March (pod harvesting season) followed by their occurrence and distribution in natural stands and homegardens. Based on their abundance and distribution, 12 seed sources covering four northeastern states of India (viz. Manipur, Meghalaya, Mizoram and Nagaland) were selected for the study (Figure 1). These seed sources were further clustered into four agroclimatic zones (viz. perhumid, humid, subhumid and arid) following the Thornthwaite (1948) climatic classification. Various agroclimatic variables such as potential evapo-transpiration (PET), precipitation, mean monthly temperature of each seed source was considered for calculating moisture index 


\section{North East India}

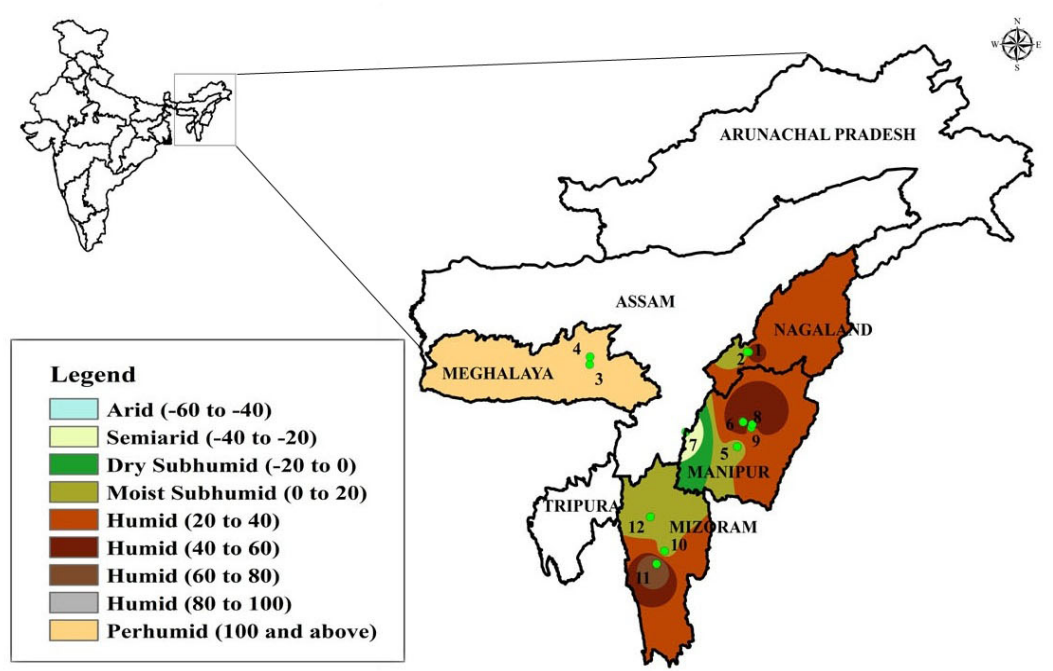

Seed Sources

1. Pherema

2. Medziphema

3. Shillong

4. Sumer

5. Bishnupur

6. Senapati

7. Jiribam

8. Langol

9. Achanbigei

10. Serchhip

11. Lunglei

12. Sakawrtuichhun

Figure 1. Map showing zonal distribution of Parkia timoriana, drawn using Arc GIS interpolation tool

(MI) and annual heat index (I) following Thornthwaite (1948) as follows:

Annual heat index, $\mathrm{I}=\sum_{i=1}^{12} \mathrm{i}$

Where, $\mathrm{i}=$ monthly heat index $=\left(\frac{\mathrm{t}}{\mathrm{s}}\right)^{1.514}$

and $\mathrm{t}=$ mean monthly temperature $\left({ }^{\circ} \mathrm{C}\right)$

PET $=1.6\left(\frac{10 . t}{\mathrm{I}}\right)^{\alpha} \cdot \frac{\mathrm{L}}{12} \cdot \frac{\mathrm{N}}{30}$

Where,

$\alpha=675 \cdot 10^{-9} \cdot I^{3}-771 \cdot 10^{-7} \cdot I^{2}+1792 \cdot 10^{-5} \cdot I+0.49239$

$\mathrm{L}=$ the theoretical sunshine hours for each month

$\mathrm{N}=$ number of days for each month.

$\mathrm{MI}=\frac{100 \mathrm{~s}-60 \mathrm{~d}}{n}$

Where, $\mathrm{s}=$ surplus water, which is defined as the sum of the monthly difference between precipitation $(\mathrm{P})$ and PET for those months when P exceeds PET (cm); $d$ = water deficiency, which is defined as the sum of the monthly difference between PET and precipitation $(\mathrm{P})$ and for those months when PET exceeds $\mathrm{P}(\mathrm{cm}) ; \mathrm{n}=$ water need, which is the sum of monthly values of PET for the surplus of deficiency months $(\mathrm{cm})$
The MI derived thus was interpolated to generate respective agro climatic map by using ARCGIS interpolation tool (Childs, 2004). Interpolation is a spatial analysis technique in which values are predicted by averaging the known point values. The moisture index values of sampling sites were used to generate a continuous surface giving us predicted value of agro climate for the entire region.

\section{B. Pod Collection and Seed Extraction}

Twenty mature pods were collected from each of ten candidate trees (twelve years old) from twelve sources representing four states of northeast India viz. Manipur, Meghalaya, Mizoram and Nagaland. These pods were harvested manually by using a scythe made from a long bamboo pole. Collected pods were then air dried for 30 days; 10 days under direct sunlight and 20 days under shade. Drying of seeds in intact pods may enhance seed maturation and seed dry weight accumulation consequently increasing viability. Measurement of the length of pod was done by using a measuring tape, while width was measured by using digital calliper. Weights of pods and seeds were taken in a digital weighing balance. Extraction of the seeds was done manually by 

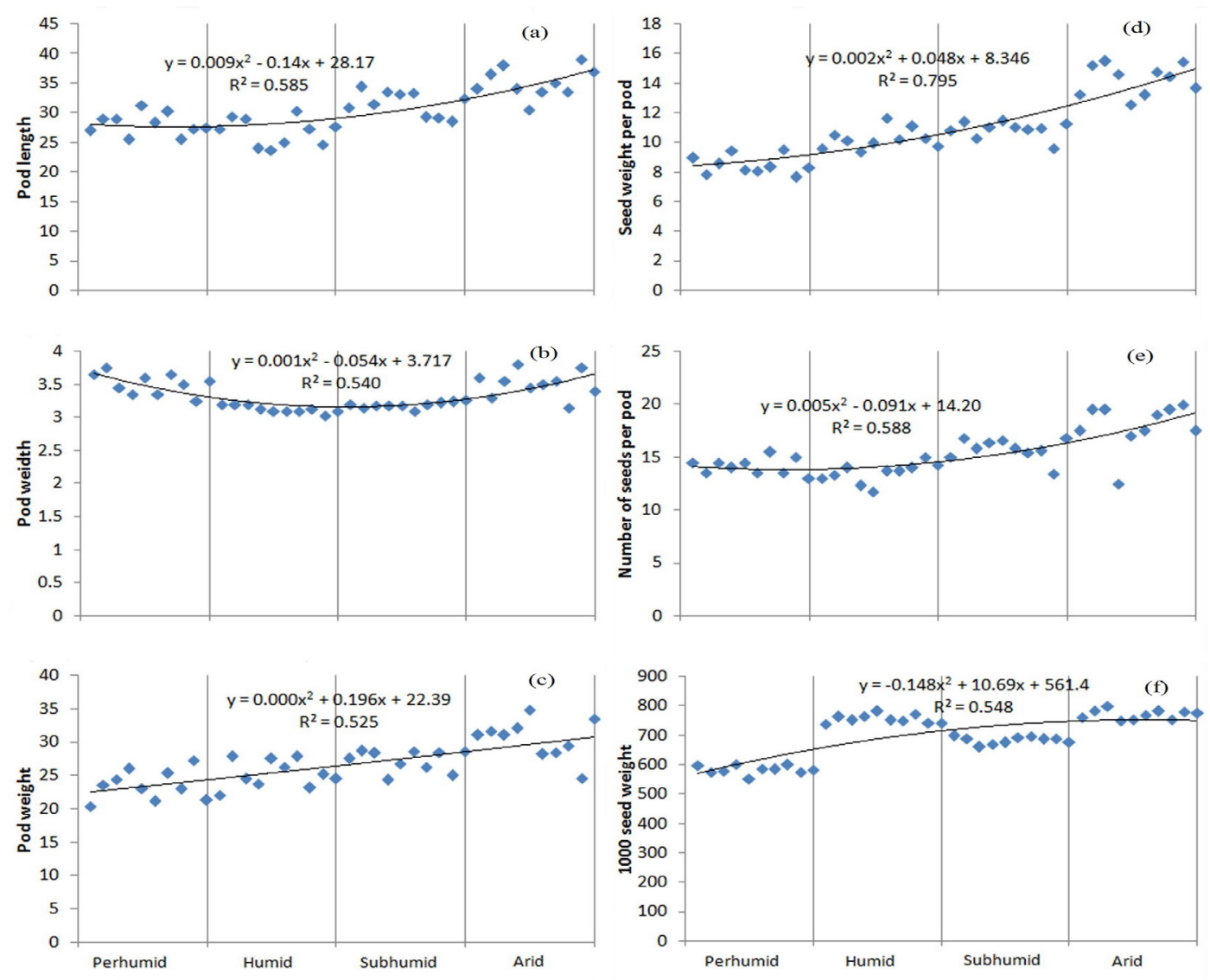

Figure 2. Effect of agroclimatic zones on pod and seed characters of P. timoriana

using secateurs and seeds with insect and fungal attack were discarded at the same time.

\section{Seed Germination and Seedling Growth Traits}

After extraction, seeds from each source were soaked in a $1000 \mathrm{ml}$ beaker filled with distilled water for 24 hours. Soaking of seeds in water before sowing enhances germination due to increased water and oxygen intake (Thangjam \& Sahoo, 2017) and can help separation of viable and non-viable seeds. A total of 384 seeds were then sown separately in polythene bags $(20 \times 17 \mathrm{~cm})$ containing sieved $(1 \mathrm{~mm})$ garden soil. Watering was done every alternate day and daily records were maintained until 30 days or till seedlings ceased to emerge. A seed is considered as germinated when a healthy white radical of about $2 \mathrm{~mm}$ length protrudes through the integument. The seedlings were allowed to grow until 90 days so as to assess various germination attributes such as: germination percentage (GP), mean germination time (MGT), germination index (GI), germination energy (GE) and seedling vigour (SV). The GP was calculated as the number of seeds germinated to the total number of seeds sown, expressed as percentage. The MGT was calculated following Scott's equation (Scott et al., 1984) as, MGT $=\sum \mathrm{T}_{\mathrm{i}} \mathrm{N}_{\mathrm{i}} / \mathrm{S}$ (where, $\mathrm{T}_{\mathrm{i}}$ is the number of days from the beginning of the experiment, $\mathrm{N}_{i}$ the number of seeds germinated per day and $\mathrm{S}$ is the total number of seeds germinated). GI was calculated following Esechie (1994) as, $\mathrm{GI}=\left(\mathrm{G}_{1} / 1\right)+$ $\left(G_{2} / 2\right)+\ldots \ldots \ldots+\left(G_{x} / x\right)$ (where, $G$ is the germination on day $1,2 \ldots$, and $x$ represents the corresponding day of germination). GE was obtained as GI at maximum daily germination speed and SV was calculated by multiplying GP with the seedling length.

Measurements were taken every 15 days starting from the two leaved stage until the completion of the study which was when?. 
Table 1. Climatic variables of 12 seed source of Parkia timoriana as per Thornthwaith (1948)

\begin{tabular}{|c|c|c|c|c|c|c|c|c|}
\hline $\begin{array}{l}\text { Sl. } \\
\text { No. }\end{array}$ & Seed source & State & $\begin{array}{c}\text { Temperature } \\
\left({ }^{\circ} \mathrm{C}\right)\end{array}$ & $\begin{array}{l}\text { Rainfall } \\
(\mathrm{cm})\end{array}$ & $\begin{array}{c}\text { PET } \\
\text { (cm/year) }\end{array}$ & MI & Code & $\begin{array}{c}\text { Agro } \\
\text { climatic } \\
\text { zone } \\
\end{array}$ \\
\hline 1. & Pherema & Nagaland & 24.29 & 322.37 & 14.3 & 80.33 & B4 & Humid \\
\hline 2. & Medziphema & Nagaland & 28 & 117.97 & 24.16 & -35.73 & $\mathrm{D}$ & Arid \\
\hline 3. & Shillong & Meghalaya & 17.43 & 353.05 & 82 & 237.46 & A & Per-humid \\
\hline 4. & Sumer & Meghalaya & 21.54 & 306.3 & 106.69 & 123.68 & A & Per-humid \\
\hline 5. & Bishnupur & Manipur & 20.47 & 123.69 & 101.76 & -3.45 & $\mathrm{C} 1$ & Sub-humid \\
\hline 6. & Senapati & Manipur & 21.82 & 153.66 & 106.54 & 24.4 & $\mathrm{~B} 1$ & Humid \\
\hline 7. & Jiribam & Manipur & 28.58 & 194.23 & 252.79 & -39.42 & $\mathrm{D}$ & Arid \\
\hline 8. & Langol & Manipur & 21.08 & 148.21 & 105.56 & 1.69 & $\mathrm{C} 2$ & Sub-humid \\
\hline 9. & Achanbigei & Manipur & 23.75 & 159.12 & 134.13 & 15.84 & $\mathrm{C} 2$ & Sub-humid \\
\hline 10. & Serchhip & Aizawl & 25.17 & 220.76 & 156.54 & 11.83 & $\mathrm{C} 2$ & Sub-humid \\
\hline 11. & Lunglei & Aizawl & 25.58 & 308.04 & 164.01 & 57.96 & $\mathrm{~B} 2$ & Humid \\
\hline 12. & Sakawrtuichhun & Aizawl & 24.92 & 254.8 & 151.52 & 3.4 & $\mathrm{~A}$ & Sub-humid \\
\hline
\end{tabular}

Growth parameters that were assessed includes: shoot length, root length, shoot dry weight, root dry weight, collar diameter, total biomass, relative growth rate (RGR), average growth rate (AGR) and seedling vigour. RGR and AGR were calculated following Thangjam and Sahoo (2017).

\section{Statistical Analysis}

Both univariate and multiple regressions were performed to examine if the regeneration and growth traits are associated with clinal and/ or climatic variation. These analyses were also used to derive a polynomial equation predicting the relationships between various traits in an agroclimate. Two way analysis of variance (ANOVA) were performed to understand if there were significant differences among agroclimatic zones for the seed and pod traits. Coefficient of variation (CV) was calculated by dividing the zonal standard deviation of a given trait (oprov) by the overall average of the zone for that trait $\overline{(X)}$. CV was compared between the sampled populations to measure the degree of genetic differences.

\section{RESULT AND DISCUSSION}

\section{A. Agroclimatic Zonation of Seed Source}

Discernable variations in temperature, rainfall, PET and MI were observed among the locations of occurrence of the twelve seed sources of $P$. timoriana (Table1). The moisture index (MI) ranged from -39.42 unit (Jiribam, Manipur) to 237.46 unit (Shillong, Meghalaya). These regions covered all four major agroclimatic zones; arid, subhumid, humid and perhumid. Minimum MI or place with maximum aridity was seen in Jiribam (-39.42), followed by Medziphema (-35.73). These regions despite having average rainfall have high potential evapo-transpiration (PET) resulting in higher aridity. Further, interpolation of the moisture index data for the twelve sample points using ArcGIS showed minor variability in prediction of agroclimatic range from that of the observed Thornthwaite zonation. This might be due to lesser number of raster points taken which decreased the probability for prediction.

\section{B. Effect of Agroclimatic Zones on Seed and Pod Characteristics}

Highly significant differences $(\mathrm{P}<0.001)$ were found for the seed and pod traits between 
Table 2. Analysis of variance on seed and pod characters of Parkia timoriana due to agro climatic zones

\begin{tabular}{|c|c|c|c|c|c|c|c|}
\hline Traits & Source & SS & df & MS & F ratio & $\mathrm{P}$ value & $\mathrm{CV} \%$ \\
\hline \multirow[t]{3}{*}{ Pod length } & Between zones & 2507.969 & 3 & 835.99 & 39.88 & $<0.0001$ & 22.3 \\
\hline & Within zones & 1249.412 & 59 & 21.18 & 1.01 & 0.466808 & \\
\hline & Error & 3710.272 & 177 & 20.96 & & & \\
\hline \multirow[t]{3}{*}{ Pod width } & Between zones & 7.354125 & 3 & 2.45 & 29.65 & $<0.0001$ & 6 \\
\hline & Within zones & 3.557975 & 59 & 0.06 & 0.73 & 0.919831 & \\
\hline & Error & 14.62993 & 177 & 0.08 & & & \\
\hline \multirow[t]{3}{*}{ Pod weight } & Between zones & 1591.709 & 3 & 530.57 & 19.05 & $<0.0001$ & 11.1 \\
\hline & Within zones & 1246.087 & 59 & 21.12 & 0.76 & 0.890859 & \\
\hline & Error & 4928.679 & 177 & 27.85 & & & \\
\hline \multirow[t]{3}{*}{ Seed weight pod ${ }^{-1}$} & Between zones & 1054.153 & 3 & 351.38 & 42.77 & $<0.0001$ & 22.1 \\
\hline & Within zones & 201.5135 & 59 & 3.42 & 0.42 & 0.999917 & \\
\hline & Error & 1454.173 & 177 & 8.22 & & & \\
\hline \multirow[t]{3}{*}{ Seed number pod ${ }^{-1}$} & Between zones & 739.1167 & 3 & 246.37 & 31.2 & $<0.0001$ & 13.2 \\
\hline & Within zones & 462.9833 & 59 & 7.85 & 0.99 & 0.497838 & \\
\hline & Error & 1397.883 & 177 & 7.90 & & & \\
\hline \multirow[t]{3}{*}{1000 seed weight } & Between zones & 1322665 & 3 & 440888.4 & 38.13 & $<0.0001$ & 12.3 \\
\hline & Within zones & 464891.9 & 59 & 7879.524 & 0.68 & 0.955842 & \\
\hline & Error & 2046396 & 177 & 11561.56 & & & \\
\hline
\end{tabular}

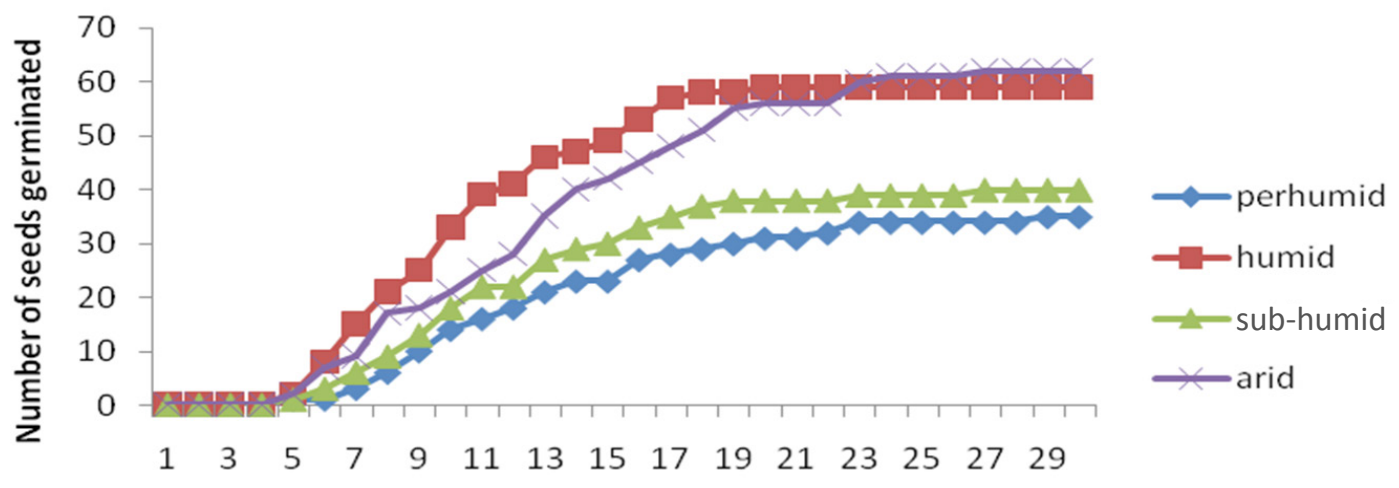

Number of days

Figure 3. Relationship between zonal distribution of P. timoriana and its germination time

the agro climatic zones of Parkia timoriana in the North-Eastern states of India (Table 2). The highest coefficient of variation among the traits was observed in pod length $(\mathrm{CV}=22.3 \%)$, closely followed by seed weight per pod $(\mathrm{CV}$ $=22.1 \%$ ) and least in pod width $(\mathrm{CV}=6 \%)$. Polynomial regression curve drawn for pod and seed characters against agroclimatic zones (Figure 3, a to $\mathrm{f}$ ) showed a gradual increase in pod length, pod weight, seed weight per pod, seed number per pod and 1000 seed weight, as one moves from from per humid to arid zone. However, pod width showed higher values in perhumid and arid zones than the humid and subhumid zones.

The speculation of this clinal pattern was very important to study as these were linked to initiation and cessation of plant growth and/or adaptation of a species to different environments. Few studies on clinal response 
Table 3. Germination behaviour of the seeds of P. timoriana from different agro climatic zones

\begin{tabular}{lccclcr}
\hline Zone & $\begin{array}{l}\text { Number } \\
\text { of seeds } \\
\text { sown }\end{array}$ & $\begin{array}{c}\text { Germination } \\
\%\end{array}$ & $\begin{array}{l}\text { Number } \\
\text { of days for } \\
\text { initiation of } \\
\text { germination }\end{array}$ & $\begin{array}{l}\text { Mean } \\
\text { germination } \\
\text { time (days) }\end{array}$ & $\begin{array}{l}\text { Germination } \\
\text { Index }\end{array}$ & $\begin{array}{l}\text { Germination } \\
\text { Energy }\end{array}$ \\
\hline Per-humid & 96 & $36.5 \pm 3.1$ & $5 \pm 2$ & $13.5 \pm 1.5$ & $13.9 \pm 1.4$ & $29.2 \pm 0.0$ \\
Humid & 96 & $61.5 \pm 16.9$ & $5 \pm 1$ & $10.9 \pm 0.7$ & $21.0 \pm 8.3$ & $49.6 \pm 13.8$ \\
Sub-humid & 96 & $41.7 \pm 11.5$ & $5 \pm 0.8$ & $12.0 \pm 0.7$ & $15.5 \pm 6.4$ & $32.9 \pm 8.1$ \\
Arid & 96 & $64.6 \pm 4.2$ & $5 \pm 0.5$ & $13.2 \pm 0.5$ & $24.5 \pm 2.9$ & $56.3 \pm 4.2$ \\
\hline
\end{tabular}

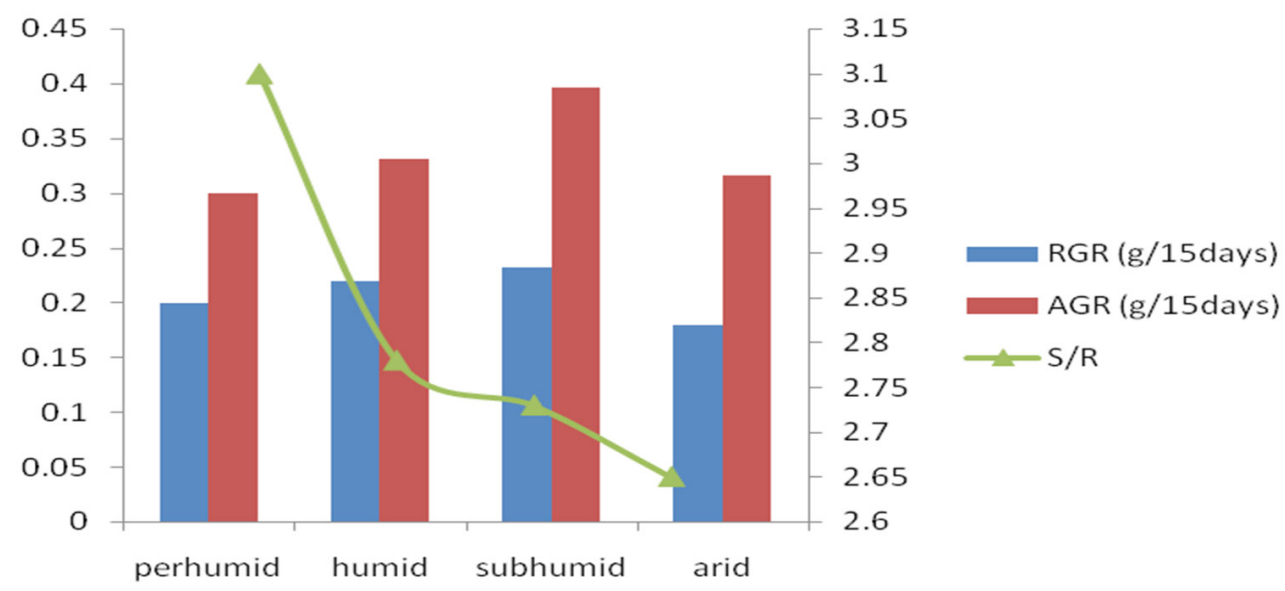

Figure 4. Effect of zonal distribution on relative growth rate (RGR), average growth rate (AGR) and shoot to root ratio $(\mathrm{S} / \mathrm{R})$ of P. timoriana

or provenance effect on Dalbergia sissoo (Singh \& Bhatt, 2008), Pinus roxburghii (Ghildiyal, Sharma \& Gairola, 2009) and Jatropha curcas (Ghosh \& Singh, 2011) pointed out the significant effects of environmental adaptation and genetic effect on defining various qualitative and quantitative traits. We observed an increase value of most of the studied traits when sampling goes from per-humid to arid zones (Figure 3). Northeast India exhibited a varied agroclimatic zones having very high rainfall and potentially lesser evapotranspiration like Shillong (Perhumid) to a place having lesser rainfall with high aridity and temperature like Jiribam (Arid). Similar climatic amplitudes was reported for Parkia biglobosa in Sudano-Sahelian zone of West Africa (Quedraogo et al., 2012).

\section{Effect of Agroclimatic Zones on Seed Germination and Seedling Growth}

Seed germination in P. timoriana seeds was found maximum in arid zone samples $(64.58 \%)$, and lowest in per-humid zone samples $(36.46 \%)$. Similarly, speed of germination and germination energy was maximum in arid and minimum in per-humid zone (Table 3). The shortest mean germination time (10.9 days) was found in humid while per-humid took the longest time (13.47 days). Cumulative germination curve (Figure 3) showed shortest germination (16 days) for humid followed by sub-humid and arid (23 days) and per-humid (27 days). The value of germinability, germination energy and germination index followed an order of arid $>$ humid $>$ sub-humid $>$ perhumid. A similar trend was seen (Figure 2f) in the regression line drawn between seed weight and agro climatic zone. This supports that arid and sub-humid zones being correspond to maximum seed weight and resulted into giving the best germination percentage. Strong positive relations between seed weight and 
Table 4. Relationship between seedling length, biomass and collar diameter after 90 days of growth for different climatic zones

\begin{tabular}{lcccccr}
\hline \multicolumn{1}{c}{ Zone } & $\begin{array}{c}\text { Seedling } \\
\text { length (sdl) }\end{array}$ & $\begin{array}{c}\text { Biomass } \\
(\mathrm{bms})\end{array}$ & $\begin{array}{c}\text { Collar } \\
\text { diameter } \\
(\mathrm{cd})\end{array}$ & Regression equation & $\mathrm{r}^{2}(\%)$ & $\mathrm{F}(\alpha=0.05)$ \\
\hline Per-humid & $57.5 \pm 2.7$ & $2.3 \pm 0.1$ & $4.5 \pm 0.1$ & $\mathrm{sdl}=185.61+65.62 \mathrm{bms}-62.44 \mathrm{~cd}$ & 28 & 0.61 \\
Humid & $55.5 \pm 2.0$ & $2.3 \pm 0.1$ & $4.4 \pm 0.3$ & $\mathrm{sdl}=4.83+25.49 \mathrm{bms}-1.77 \mathrm{~cd}$ & 96 & $7.96 \mathrm{E}-05$ \\
Sub-humid & $60.8 \pm 2.1$ & $2.7 \pm 0.1$ & $5.1 \pm 0.1$ & $\mathrm{sdl}=44.58+14.08 \mathrm{bms}-4.18 \mathrm{~cd}$ & 54 & 0.0099 \\
Arid & $66.9 \pm 4.7$ & $2.5 \pm 0.2$ & $4.8 \pm 0.2$ & $\mathrm{sdl}=22.05 \mathrm{~cd}-2.29 \mathrm{bms}-32.23$ & 88 & 0.042 \\
\hline
\end{tabular}

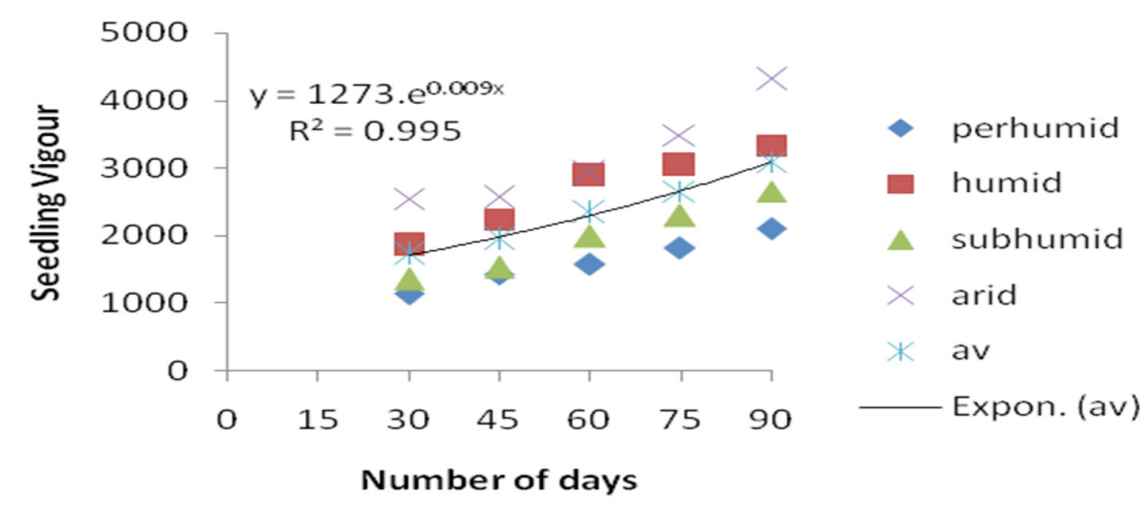

Figure 5. Relationship between seedling vigour, zonal distribution and time in days, taken alternately after every 15 days interval

germinability were also reported earlier for this species (Thangjam \& Sahoo, 2016). Multiple regression analysis showed significant $(\mathrm{P}<0.05)$ variations between seedling length, biomass and collar diameter humid, sub-humid and arid zone. Similarly the coefficient of determination of the above parameters revealed that these three zones have more than $50 \%$ values that fit the model (Table 4). Per-humid zone on the other hand gave poor determination coefficient $\left(\mathrm{R}^{2}=28 \%\right)$ along with non significant $\mathrm{F}$ value (0.61).

The effect of zonal distribution on the rate of growth of the seedling (RGR), average growth rate (AGR) and shoot to root ratio is shown in Figure 4. RGR was highest for seeds from sub-humid zone $(0.232 \mathrm{~g})$ while lowest for seeds from arid zone $(0.179 \mathrm{~g})$. Average growth rate (AGR) after 90 days was maximum for seeds from sub humid zone (0.396 g), while minimum from per-humid zone $(0.299 \mathrm{~g})$. On the contrary, ratio of root to shoot in biomass production revealed that seeds from perhumid zone accounted to maximum difference (2:6.19) while minimum was found in arid zone (2:5.30).

Simple regression curve between seedling vigour and number of days (Figure 5) showed a distinct growth line in the average growth whose observed values are least deviated from the mean $\left(R^{2}=0.995\right)$. Seeds drawn from arid zone gave the maximum seedling vigour while per-humid zone resulted in minimum seedling vigour. Therefore using these equations one could predict a dependent value by knowing the other two independent values. Along with germination parameters, above seedling growth parameters also correspond to high value in case of arid and sub humid zones. Our results are in conformity with the findings of other workers (Souza \& Fagundes, 2014; Kolodzijek, 2017) who acknowledged that seed size and weight have strong influence on germination as well as growth and biomass of a plant. The environmental influences in our study were presumed to be minimal as the seedlings from all seed sources were grown in a 
commongreenhouse environment. The results further support the hypothesis that geographic and ecological clines could influence the seed, pod and seedling traits to a great extent.

\section{CONCLUSION}

Significant variation in seed, pod and regeneration characters of $P$. timoriana from four agroclimatic zones were observed. In a glasshouse trial conducted in the XX climate zone the performance of the species in terms of germination and seedling vigour was in the order of arid $>$ humid $>$ sub-humid $>$ perhumid. This performance was strongly related to seed weight and pod size irrespective of the source. Though the species shows wide ecological amplitude, the arid climate yields the best results.

\section{ACKNOWLEDGEMENT}

The senior author (UT) gratefully acknowledges financial support in the form of a research fellowship from the Union Grants Commission (UGC), New Delhi, India, to conduct this study.

\section{REFERENCES}

Aigbe, H.I., Fredrick, C., \& Omokhana, G.E. (2016). Effect of seed source on germination and early seedling growth of Heinsia crinite (Afzel.) G. Taylor. Applied Tropical Agriculture, 21(3), 180-185.

Childs, C. (2004). Interpolating surfaces in Arc GIS spatial analysis. Arc User, (July-Sept), pp 32-3 Retrieved http:/www.esri.com/news/ arcuser/0704/files/interpolating.pdf on 15 July 2018.

Esechie, H. (1994). Interaction of salinity and temperature on the germination of sorghum. Journal of Agronomy and Crop Science, 172, 194199.

Fredrick, C., Muthuri, C., Ngamau, K., \& Sinclair, F. (2015). Provenance variation in seed morphological characteristics, germination and early seedling growth of Faidherbia albida. Journal of Horticulture and Forestry, 7(5), $127-$ 140.
Gardarin, A., Coste, F., Wagner, M., \& Dürr, C. (2016). How do seed and seedling traits influence germination and emergence parameters in crop species? A comparative analysis. Seed Science Research, 26(4), 317-331.

Ghildiyal, S.K., Sharma, C.M., \& Gairola, S. (2009). Environmental variation in seed and seedling characters of Pinus roxburgbii Sarg. From Uttarakhand, India. Applied Ecology and Environmental Research, 7(2), 121-129.

Ghosh, L., \& Singh, L. (2011). Variation in seed and seedling characters of Jatropa curcas L. with varying zones and provenances. Tropical Ecology, 52(1), 113-122.

Gupta, G., Handa, A.K., Ajit, \& Maurya, D. 2016. Variation in seed and seedling traits of Pongamia pinnata. Indian Forester, 142(9), 852857.

Hopkins, H.C.F. (1986). Parkia (Leguminosae: Mimosoidae), Flora neotropica Monograph, 43, The New York Botanical Garden, New York, pp 1-123.

Hopkins, H.C.F. (1994). The Indo-Pacific species of Parkia (Liguminosae: Mimosoidae). Kew Bull, 49, 182

Kolodzijek, J. (2017). Effect of seed position and nutrients on seed mass, germination and seedling growth in Peucedanum oreoselinum (Apiaceae). Scientific Reports, 7, 1959-1969.

Moya, R.S., Meza, S.E., Díaz, C.M., Ariza, A.C., Calderón, S.D. \& Peña-Rojas, K. (2017). Variability in seed germination and seedling growth at the intra and interprovenance levels of Nothofagus glauca (Lophozonia glauca), an endemic species of Central Chile. New Zealand Journal of Forestry Science, 47, 10.

Palinikumaran, B., Parthiban, K.T., Sekar, I., Umarani, R., \& Amirtham, D. (2015). Variability studies for seed and seedling traits in Undi (Calophyllum Inopbyllum L.) from different Zoneso South India. Journal of Plant Science and Research, 2(2), 124.

Quedraogo, M., Ræbild, A., Nikiema, A., \& Kjær, E.D. (2012). Evidence for important genetic differentiation between provenances of Parkia biglobosa from the Sudano-Sahelian zone of West Africa. Agroforestry System, 85, 489-503.

Raebild, A., Hansen, U.B., \& Kambou, S. (2012). Regenerarion of Vitellaria paradoxa and 
Parkia biglobosa in a parkland in Southern Burkina Faso. Agroforestry System, 85(2), $443-$ 453.

Rathi, R.S., Misra, A.K., Roy, S., Verma, S.K., \& Singh, S.K. 2012. Potential of a lesser known tree species Parkia roxburghii G. Don of North East India. Indian Forester, 138(5), 476479.

Roy, S.S., Kumar, S., Sharma, S.K., Devi, A.R., Singh, N.A., Prakash, N., \& Ngachan, S.V. (2016). Tree Bean (Parkia roxburgbii): A potential multipurpose tree legume of North East India. National Symposium on Vegetable Legumes for Soil and Human Health, $12^{\text {th }}$ to $14^{\text {th }}$ February 2016, Indian Institute of Vegetable Research (IIVR), Varanassi, pp 201-208.

Salam, J.S., Singh, P.K., Dutta, B.K., \& Sahoo, U.K. (2009). Chemical composition and nutritive indices in Parkia roxburghii G. Don, a leguminous plant of India. Indian Journal of Agricultural Biochemistry, 22(2), 87-93.

Salam, J.S., Singh, P.K., Dutta, B.K., \& Sahoo, U.K. (2010). Effect of processing and cooking methods on some anti-nutritive, toxic components and nutritional constituents in stink bean (Parkia roxburgbii G. Don) seeds. Indian Journal of Agricultural Biochemistry, 23(2), 97-102.

Singh, B., \& Bhatt BP. 2008. Provenance variation in pod, seed and seedling traits of Dalbergia sissoo Roxb., Central Himalaya, India. Tropical Agriculture Research \& Extension, 11, 39-43.

Sniezko, R.A., \& Stewart, H.T.L. (1986). Range-wide provenance variation in growth and nutrition of Acacia albida seedlings propagated in Zimbabwe. Forest Ecology and Management, 27(3-4), 179-197.
Souza, M.L., \& Fagundes, M. (2014). Seed size as key factor in germination and seedling development of Copaifera langsdorffi (Fabaceae). American Journal of Plant Sciences, 5, 2566-2573.

Teklehaimanot, Z. (2004). Exploiting the potential of indigenous agroforestry trees: Parkia biglobosa and Vitellaria paradoxa in subSaharan Africa. Agroforestry System, 61, 207220.

Thangjam, R., Damayanti, M., \& Sharma, G.J. (2003). Cadra cautella Walker (Lipidoptera: Crambidae: Phycitinae) - A pest on Parkia timoriana (DC.) Merr. in Manipur. Current Science, 85(6), 727-726.

Thangjam, U., \& Sahoo, U.K. (2016). Effect of seed mass on germination and seedling vigour of Parkia timoriana (D.C.) Merr. Current Agriculture Research Journal, 4(2), 171-178.

Thangjam, U., \& Sahoo, U.K. (2017). Effects of different pre-treatments and germination media on seed germination and seedling growth of Parkia timoriana (D.C) Merr. Journal of Experimental Biology and Agriculture Science, 5(1), 98-105.

Thornthwaite, C.W. (1948). An approach towards a rational classification of climate. Soil Science, 66, 77.

Tomar, A., \& Rattan, V. (2012). Seed source variation in fruit, seed and seedling traits of Hippophae salicifolia. International Journal of Pharmacy \& Lifesciences, 3(12), 2181-2185.

Xu, Y., Cai, N., He, B., Zhang, R., Zhao, W., Mao, J., Duan, A., Li, Y., \& Woeste, K. (2015). Germination and early seedling growth of Pinus densata Mast. Provenances. Journal of Forestry Research, 27(2), 283-294. 